\title{
Unsettling sight: Judith Wright's journey into history and ecology on Mt Tamborine
}

\author{
Stuart Cooke \\ stuart.cooke@griffith.edu.au
}

\begin{abstract}
Mt Tamborine is a crucial location for Judith Wright's poetry, and for the development of her thought. She wrote the majority of her poetry collections while living on the mountain from 1948-75; it was there that she came face to face with the complexities of Australian ecologies and colonial histories. While her earlier poems from this period reflect a concerted, anti-colonial desire to separate the world of Tamborine from her European inheritance and perspective, by the early 1970s her work becomes preoccupied with symbiotic relationships between her body, her house and garden, and the surrounding landscape. This turn reflects broader shifts in thought in the mid-twentieth century, where notions of separation and precision were being problematised by the emerging field of quantum mechanics.
\end{abstract}

The hinterland of South-East Queensland, and more specifically Mt Tamborine, are fundamental locations for the genesis and development of Judith Wright's poetry and thought. Given Wright's importance to twentieth-century Australian literature, Mt Tamborine deserves recognition as a site of major significance in the mythological landscape of Australian culture. It is certainly true that much of Wright's work - in both poetry and prose - deals explicitly with her upbringing within a New England pastoral family, and a much broader audience would have become familiar with her social and environmental activism after she had moved to the outskirts of Canberra in the late 1970s, when her poetic output declined significantly and, in its place, she began to publish increasing amounts of prose. Nevertheless, the importance of Mt Tamborine and South-East Queensland ecology to the development of Wright's poetry and politics cannot be over-stated, although it has been somewhat neglected to date. Indeed, after Wright moved to Mt Tamborine with Jack McKinney in 1948, and until her departure for Canberra in 1975, the vast bulk of her poetic work was written there, or while she called the region her home. She would publish the most important volumes of her career while a resident on the mountain, and some of the most important collections in the history of Australian poetry. ${ }^{1}$ 
Part of the Gold Coast hinterland of South-East Queensland, Tamborine Mountain lies 45 kilometres south of Brisbane. The plateau of the mountain and its surrounding foothills cover about 12 square kilometres; the plateau itself is about 8 kilometres long, 5 kilometres wide and rises to an altitude of 525 metres. Such elevation keeps the temperature slightly cooler than the surrounding lowlands, which makes it attractive for the many writers, artists and academics who now live there in the various communities that lie scattered between the different reserves. Tamborine National Park is composed of fourteen separate reserves, which are home to a wide range of forest types, including sub-tropical rainforest, wet eucalypt forest and open eucalypt forest, all of which house more than 900 different species of plants. This number represents 65 per cent of all the plant species found in the 'mega-diverse' bioregion of the Gold Coast area, along with 85 per cent of all fauna species, including the fabled Albert's Lyrebird, platypuses, brush-turkeys, lorikeets, eastern whipbirds, and satin and regent bowerbirds. ${ }^{2}$ By any measure, Tamborine is an extraordinary part of the world.

Wright's 'escape' to Tamborine in the late 1940s is often framed as an attempt to avoid the critical glare that would no doubt have surrounded her relationship with a married man who was twenty years her senior. What this received narrative neglects, however, is the way that, on 'escaping' the stifling pressures of post-war culture in Queensland, moving to Tamborine brought Wright face to face with some of the most complicated and diverse ecological systems on the planet. In turn, the European garden of their home, 'Calanthe' - backing as it did onto temperate rainforest - was a profound local illustration of the broader impacts of colonisation on the Australian environment. By looking closely at some of the poems she wrote during this period, then, we can see how Wright's residence on Mt Tamborine honed her attentiveness to the complex agencies of the non-human world - a world that would lead her to the very brink of language and thought, where poetry was to become the articulation of that limit. Consequently, one of the defining features of her poetry from this period is a marked limitation of the speaker's vision; the speaker, however empathetic or desirous of empathy with what surrounds her, is restrained by an irresolvable incomprehension. The need of the poet to nevertheless name that which must remain unknown therefore produces a recurrent tension in Wright's Tamborine-era poetics.

'Conch Shell', ${ }^{3}$ from the first of Wright's Tamborine volumes (Woman to Man, 1949), is a very useful early example of her attempts to articulate an explicitly ecological set of relations between a Romantic lyric subject and the wider world, the outcomes of which would prove both fruitful and frustrating for much of the rest of her life. Initiating a process of trans-species metamorphosis, the speaker of the poem attempts to identify completely with, or to embody, another life form:

... I contract

into a beast's blind orbit, stare deep down

the cliffs not I have climbed ...

Importantly, this dramatic 'contraction' occurs just before the poem's conclusion, alerting us to the fact that, for the lyric to sing to someone, someone else must be doing the singing. That is to say, in 'Conch Shell' the speaker is quite adept at describing the various, external features of the shell; when, however, she begins 
to probe its 'senseless life', she is in effect sacrificing her own. When life becomes 'senseless' - to live without sense, or without a discrete 'I' that 'knows' sense - the lyric cannot exist. 'Conch Shell', therefore, is an important example of a modern lyric that 'attempts the impossible', to use Geoffrey Hartman's words. Such a lyric is 'a monument to spontaneity, a poem that coincides with the act and passion of its utterance'. ${ }^{4}$ So great is this passion, so spontaneous is its release, that it leads 'Conch Shell' into the realms of the senseless and then, in a manner of selfannulment, on to an empty white page. Here, language has become coterminous with life: it speaks when things need to be spoken; it does not try to represent the unspoken or the unspeakable; it is not elegiac or at a second order to life itself. The lyrical subject, like all things, can flare brilliantly, but must also eventually wither. What 'Conch Shell' foregrounds for us here is not only that Wright was willing to journey to the limits of the lyric form, but also that the capacity of the lyric voice to speak for all things was being questioned from a very early stage in her career.

Elsewhere in the same volume, in 'The Cycads', 5 lyrical passion takes her to the 'unthinkable, unfathomed edge' between human consciousness and the vast biosphere of 'rising forests' and 'complicated birds and flowers'. The ancient cycads, prominent members of Mt Tamborine's ecosystem, are trees whose 'smooth dark flames flicker at time's own root'. Here we see deep, historical energies drawn upon to produce 'complicated' and 'brilliant' ecologies that, for all their ebullience, can only feature as objects in a scene; to enter such a system would require that the human descend into a 'sleep' reminiscent of the silence with we are left in 'Conch Shell'. Again, the English poem has reached its limit. Wright is proposing two alternatives: (1) to continue within the English language and within poetry, but at the same time to continue at a remove from the worlds that such a language tries to describe; or (2) to forgo language, and the thought that generates it, and to be subsumed within the unfathomable depths of non-human relation.

However, Wright never approaches the realm of the non-human as a purely dehumanised plane of existence. From her earliest poems in The Moving Image (1946), she is a poet keenly aware of the relationship between European colonisation, Aboriginal dispossession and her own capacity to wander unhindered through 'wilderness' spaces like those on Mt Tamborine. Environmental history is part of Aboriginal history, just as environmental degradation is linked to European invasion and the destruction of the continent. Ultimately, this leads to close relationships with pioneering Aboriginal activists like Oodgeroo Noonuccal (who visited Calanthe often) and Nugget Coombs, and the formation of the Aboriginal Treaty Committee. In terms of her understanding of ecological complexity, however, Wright's awareness of Aboriginal dispossession means that, for her, 'the environment' is hidden beneath the crimes of her ancestors. Wright's complexity therefore has both ecological and Aboriginal-historical features: the ecological complexity of Tamborine is key here; what she learns about the mountain both during her own research and in discussion with Oodgeroo means that Tamborine becomes a source of inspiration for her critique of 'landscape', and also that we cannot label Wright as a 'landscape poet'. For Wright, the word 'landscape' is inextricable from colonialist vision: 'It is a painter's term,' she writes, 'implying an outside view, a separation, even a basis of criticism. We cannot see it against the reality of that earth-sky-water-tree-spirit-human complex existing in space-time, which is the Aboriginal world. ${ }^{6}$ This important confluence of ecology, spirit, history and future 
in Aboriginal Country marks what for Wright is the primordial world, or the world from which the coloniser and the colonial tongue are irredeemably separated. As the prehistoric cycads coexist with innumerable, more recently evolved forms in the forests of Mt Tamborine, the past coexists in the present with evolution of Country.

Yet the distinct faultline between the comprehensive nexus of Country and the comparatively impoverished spatial world of the coloniser becomes a source of much of the pathos in Wright's poems. While the lyric voice is often responsive and sensitive to the different features of this nexus, there is nevertheless a very clear sense in which such a response is at best partial, and that what is significant can at best be guessed at, or described only in abstracted terms. Certainly, the resultant pathos is highly productive, and functions as the motivating force of some of her finest poetry, such as 'At Cooloola'. ' Set at Lake Cooloola, on the Sunshine Coast north of Brisbane, 'At Cooloola' is arguably one of Wright's most important poems, and central to her poetics and politics. The speaker is a 'stranger' who has come from 'a conquering people' to watch '[a] blue crane fishing in Cooloola's twilight'. She is, as in most modern lyrics, rendered solitary, 'unloved by all [her] eyes delight in', yet she is not the typically isolated subject of modernist literature either: it is her keen awareness of the lake's dark history that simultaneously reveals the limits of her understanding and the way it is nevertheless interconnected with the rest of the field.

In 'At Cooloola', the speaker's limits have formed as a consequence of her own searching for them: she can know that 'earth is spirit', but not what this might look or feel like. This is enacted in an intriguingly bodily way in the poem, too: as she responds to the lake, the lake is also careful to propose boundaries to limit the extent to which she can respond to it; she is 'challenged by a driftwood spear / thrust from the water'. What might have been a poem about a facile separation between subject and lake is replaced by a set of complicating, post-invasion relationships. ${ }^{8}$ Indeed, we could characterise this very limited, very partial set of relationships between the speaker and her field as distinctly ecological: in any ecosystem, most organisms will occupy small, but thoroughly interconnected, niches. However, as I have written elsewhere, for all of these complicated relationships, 'At Cooloola' is nevertheless a colonial poem, its colonialism betrayed by the way in which it is ordered according to particular inherited conventions of English poetry (such as a stern, semi-regular iambic foot, end-rhyme and four-line stanzas). This contradiction, between the complexity of an environment and the simple structures of an archaic English form, leads to what I have termed a 'lapse' between Wright's political and poetic practice. ${ }^{9}$ Still, for the purposes of this essay, this is a side-issue; what is of concern here is the influence of the diverse ecology of South-East Queensland on Wright's poetics in such poems, and how her exposure to this complexity led her to formulate a necessarily limited politics, where the capacities of poetry, language and thought shrank next to vast environmental and Aboriginal histories.

Perhaps this complicated 'double movement' - of simultaneous attention to, and withdrawal from, the natural world — is epitomised in 'Lyrebirds', ${ }^{10}$ from the popular Birds collection of 1962. As a whole, Birds illustrates Wright's intimacy with Tamborine's fauna; many of the poems are characterised by a tender, often familial care for their avian subjects. In 'Lyrebirds', however, Wright agonises perhaps more than anywhere else about the distinction between what she knows or 
imagines to be '[o]ver the west side' — the largely uninhabited side — of Tamborine, and what she can see of it. In an important sense, the lyrebirds of the poem not only represent the Albert's Lyrebird of South-East Queensland, but are also symbolic of what Wright believes, in classic Romantic fashion, to be an endangered form of language and perception. The lyrebirds are therefore 'the few, the shy, the fabulous, I the dying poets', the custodians of a primordial art that has been smothered by modern thought. What occurs next, however, is quite extraordinary. The third stanza takes us into an imaginative realm, where the speaker tells us what the birds might look like, and what they might do, if she 'should see them, if [she] lay there in the dew'. The scene is quite beautiful: first there is a single trace of movement 'like a waterdrop falling', before stillness returns. Then the brown head of the lyrebird appears, 'bearing / like a crest the symbol of his art'. The symbol, we can guess, is 'the perfect lyre'; it is almost as if it is too perfect, because Wright immediately retreats from the imaginary glade to tell us bluntly, 'No, I have never gone'. What we just saw was pure speculation because Wright's 'poethics' - to use Joan Retallack's term ${ }^{11}$ - prohibit her from articulating what that 'symbol of his art' might represent; instead, she says, 'Some things ought to be left secret, alone'. The tension in the poem comes from the fact that the poem proposes the possibility of a primordial, redemptive poetics, but simultaneously, in a moment of almost hysterical anti-colonialism, keeps us from it. Wright doesn't want to 'scape' what she nevertheless imagines as a form of landscape; she wants it to be protected, hidden from colonial eyes like the matrix of Aboriginal Country.

The redemptive qualities of this primordial [Australian] poetics are symbolised in 'Lyrebirds' by the Orphic 'master' with his 'perfect lyre' - who, of course, isn't humanoid like Orpheus, but a bird. For Wright, what is redemptive about primordial or pre-modern language is its 'closeness' to the nature of things. Wright argues on a number of occasions that as a language acquires more speakers over successive generations, it necessarily becomes removed from the world, burying flowing, individual potentials ever deeper under successive, rigid layers of group experience. ${ }^{12}$ For Wright, this has become such a pressing problem because, if we pause to analyse the constant flow and movement of what she calls 'the inner life', we will realise that a good deal of it - because of its various gradations, moods and tones - simply cannot be expressed in simple, abstracted terms. ${ }^{13}$ Curiously, however, such language is often exactly how Wright chooses to search for this 'primordial' connection between human and world. Indeed, even the lyrebird of this poem is not a specific creature, but part of a pluralised archetype. By utilising such abstracted and symbolic language, her poems often prevent the very search that motivated their composition in the first place. The lyrebirds, then, bear some resemblance to a poet like John Shaw Neilson, whom Wright admired tremendously. Neilson was a poet of light and iridescent vision, whose poems evoked a flowing, interconnected world that brimmed with energy and near-magic potential. ${ }^{14}$ Although Wright wrote of these poets - bird and human alike - with such admiration, in her own poems she would invariably remain at a distance from their affective powers.

In light of such issues, it is interesting to compare Les Murray's 'Lyre Bird'15 with 'Lyrebirds' because of how the two poems signify such markedly different examples of settler poetics. We have seen that Wright is so careful of not seeing in reality the shimmering simulacra produced by her imagination; Murray, on the other hand, has no such qualms. Indeed, read together, Murray's 'Lyre Bird' and 
Wright's 'Lyrebirds' are emblematic of broader disagreements about politics and history between the pair. ${ }^{16}$ For Murray, the world is given to him by virtue of the glory of God (to which all his books are dedicated); through God's eyes all is, or can be made, apparent. In a nationalist context, too, by identifying with '[White] Australian country people' he suggests his relationship to the land is 'comparable with Aboriginal attachment [to Country]. ${ }^{17}$ In stark contrast to Wright, Murray enjoys almost completely open access to the land before him; the only thing he needs to do is find the right words for it. In large part, this distinction manifests as two remarkably different poems about the same bird. ${ }^{18}$ For each poet, poetics is deeply connected to broader understandings of politics, history and ecology; whereas for Wright this produces a poem in which the speaker must not see what might, potentially, be seen, for Murray the bird's magnificence is an invitation to exercise his similarly magnificent linguistic gifts to embody and to translate, semantically and musically, the language of this non-human poet:

I mew catbird, I saw crosscut, I howl dingo, I kink

forest hush distinct with bellbirds, warble magpie garble, link

cattlebell with kettle-boil; I rank ducks' cranky presidium

or simulate a triller like a rill mirrored lyrical to a rim.

-..

Screaming Woman owl and human talk: eedieAi and uddyunnunoan.

The miming is all of $\mathrm{I}$.

The complex syntactical rhythms in Murray's poem are suggestive not only of the vast range of lyrebird poetics, but also of Murray's consideration of the impact of an avian consciousness on English language structures. Wright's image, on the other hand, is purely pictorial, possibly cinematic, and only captures the bird at a distance, on top of which is the crucial fact that such an image is imagined: it is a cognitive representation, an image of thought, and nothing to do with what might be 'down there' on the west side of that mountain.

Coming back from the other side of Mount Tamborine to Wright's own backyard, however, 'The Flame Tree Blooms', ${ }^{19}$ from Shadow (1970), brings that primordial, Orphic power of the imagined lyrebird into the poet's immediate proximity. In real time now, the poem explicitly maps the ecological field of her garden onto the speaker's cognition, and thereby implicates such ecology in personal, historical patterns of presence and absence, and arrival and departure:

drawing up from the very roots of being

this pulse of total red that shocks my seeing

into an agony of flower.

It was you planted it;

and I lean on the sill to see it stand

in its dry shuffle of leaves, just as we planned, these past years feeding it.

What is perhaps most noticeable in 'Flame Tree' is that the unspeakable perfection that is only imagined in 'Lyrebirds' is here brought so close to the speaker that it burns like a flame 'into an agony of flower'. No longer under her control in the realm of the imagination, the overwhelming, synesthetic or visual-tactile qualities of the event are only off-set by the turn to 'you' - no doubt McKinney — who 
planted the tree eighteen years ago upon their arrival at Tamborine. As the tree has grown up to take his place, he re-emerges here to counter the 'agony' of the tree's beauty. This is perhaps the most intense coupling, and dramatic de-coupling, of speaker and environment that we have seen in the poems looked at here, but in her relationship to time and memory the speaker can be understood within a particular context of modernity identified by Martin Harrison:

it is the figure of time passing, of the poem holding that moment in a phase of appearance and disappearance, and of the poet's own reckoning with the fragility and non-reality of 'state of mind' issues connected with this moment of perception. ${ }^{20}$

Contextualised in this way, the patterns that I have identified in some of Wright's poems are indicative of a broader preoccupation amongst many modern Australian poets: the problematic correspondence (or non-correspondence) of presence (attachment to place) and absence (the erosion of habitats). Harrison finds similar patterns in poets like David Campbell and Robert Adamson ${ }^{21}$ but, to return this discussion to its original geography, it is clear that for Wright these structures were of immediate and lasting concern during her time on Mt Tamborine.

Yet it is possible to read something of a reconciliation between the settler's colonial-lyrical vision and Tamborine's ecological complexity in the work that Wright wrote towards the end of her time there. 'Habitat' (from Alive, 1973), for example, articulates a complex, multi-species environment in which many nonhuman things - animate or otherwise - find their homes. Instead of enforcing, protective boundaries around non-human ecologies, as we see in the earlier poems, the speaker in 'Habitat' now lives within an ecology. Philip Mead's important chapter on Wright in Networked Language formulates this claim in compelling fashion:

In Wright's poem ['Habitat'] then, the house, which appears to be the same age as her speaker, is part of nature as much as of the built environment ... 'habitat' is a word that, rather than anthropomorphising the house, exclusively and androcentrically, conjoins the human and the living non-human ... Hence the uncoupling of this imaginary of landscape and dwelling from the 'natural history' of settlement and settler toponymy, but also, just as significantly, from an older ecological paradigm of the individual and the species. ${ }^{22}$

Thus Wright's Tamborine property - which could include both the house and the garden around it - is no longer the setting against which she opposes the ecological and historical Other of the surrounding country. It is telling too, of course, that the poem makes no reference to Mt Tamborine as a place name: as Mead points out, the poem deliberately resists 'the elision of indigenous toponymy inherent in the nomination of white settlement'. ${ }^{23}$ Instead, rather than a humanist ethics based on traditional paradigms of ethnicity and ecology, a highly progressive notion of post-human symbiosis, both between bodies, and within the speaker's own body, is central to this poem:

We're perishable, house,

but nourishing,

I too am a hostess

for numerous inhabitants - 
a rich bacterial fauna.

Symbiosis -

that's our fate,

my wooden house. ${ }^{24}$

In part, the acknowledgement of symbiosis is based on a more simple acknowledgement that Wright, for all her care not to disturb it, was always drawing on the resources that Tamborine provided her and, in so doing, was implicitly entering into a relationship with the area. The house, then, was something of a nexus in which human and non-human beings entered into domestic relation:

Your old trees dying warmed us with winter fires.

Your birdcalls, mice in cupboards, snakes in the garden, made welcomes and nuisances for us, panics and symbols.

We ceased to be strangers.

Oiling your creaking hinges,

cursing your ill-hung doors, we changed in mute exchanges. ${ }^{25}$

None of this, however, is necessarily less colonialist than simply occupying and exploiting an area's resources. Accordingly, what saves Wright from assuming any more than she might be able or allowed, is the affirmation that she, like her wooden house, will decay and die. In a move that faintly echoes what happened in 'Conch Shell' decades earlier, the assumption of relation is mediated by the limitations of the organic organism; symbiosis is predicated on myriad, temporary histories that connect and disconnect according to biological patterns of life and death.

Symbiosis is not just a description of an ecological relationship, however, but also suggests a powerful decolonising ethics. A resultant example is 'The Dark Ones' (from Fourth Quarter, 1976), ${ }^{26}$ a poem that derives much of its haunting mood from its repeated evocations of fragmented, wounded bodies and diurnal alternations of life and death. Principally, the power is produced in a decidedly biological space, with cyclical reiterations of organic processes and a decidedly limited, grounded voice (only from 'the other side of the road' can we observe the town's Aboriginal population). To add to the complexity, our bodies - importantly, the poem uses a first-person plural voice throughout - aren't sacrosanct: something 'leaks in our blood / like the ooze from a wound'. Those other bodies are not simply inanimate objects in a landscape; they participate within our worlds, as we do in theirs. As those 'mute shadows' enter the town 'on pension day', it would appear that settler culture is momentarily unsettled: 'white talk dies away' and a 'shudder ... / runs through the town'. Evocative of that most symbolic of symbioses, yin and yang, 'night ghosts' arrive to reclaim a land that is 'only by day possessed'. On day's other side, this is the dark underbelly of colonial settlement, 'a depth that rhymes our pride / with its alternative'. But things are not this symmetrical: biological patterns of symbiosis and decay have been disrupted and buried by inorganic structures; 'faces of pale stone' banish those dark ghosts back to the margins they came from and ' $[\mathrm{w}]$ ith a babble of shamed relief / the bargaining goes on.' Again, as in previous poems, the momentary perception of a scene is problematically coupled with its propensity to vanish, but this time what might vanish is not only the outside world. Rather, we are left wounded, and the loss of our blood suggests that our own presence might also be ephemeral. 
Arguably, the position adopted in poems like 'The Cycads' and 'Lyrebirds' was untenable for Wright: for all that it purported to save or protect, it also was a source of underlying frustration, and even pain. In these poems, language is both the means by which we come into contact with the world and the means by which that same world is destroyed. However, she could not simply adopt, as the Jindyworobaks had done before her, an Aboriginal perspective and assume, on that basis, a seamless ontological fabric composed of her and all other things. While she admired the Jindyworobaks' ethos, she was also wary of the problematic consumption and translation of Aboriginal culture. Instead, writes Clark:

She sought to develop a sense of inhabiting the land through the terms and concepts provided by her own culture ... as opposed to falsified identification with an imagined Aboriginal mode of dwelling $\ldots{ }^{27}$

Such 'terms and concepts' include those of 'symbiosis' and 'habitat', terms derived from contemporary paradigms of biological systems, which paid attention to all kinds of creatures, along with their 'life worlds'. The fragility of the modern poet's state of mind is equated with the fragility of all ecological systems; in turn, such fragility becomes a form of ethics: sense, language and relation are indeed possible, but they are only ever partial, and premised on important, symbiotic customs of open habitation and organic lifespans.

These last comments point to the profound impact of the modern sciences on Wright's work, but in no sense is this meant to suggest that her poems seek the same kind of objective clarity that certain models of science might prescribe. Indeed, it is the late-modern turn towards uncertainty in fields such as quantum theory that correlates so strongly with Wright's symbiotic turn in her later work. Contemporaneous with Wright, pioneering physicist Werner Heisenberg, for example, opposes the adaptability of what he terms 'natural language' to the idealised nature of scientific language: the former, he argues, has far greater resilience and stability. Of the adaptability of such 'natural words', he writes:

It is true that they are not very well defined and may therefore also undergo changes in the course of the centuries, just as reality itself did, but they never lose the immediate connection with reality. On the other hand, the scientific concepts are idealizations ... through this process of idealization and precise definition the immediate connection with reality is lost. ${ }^{28}$

For Heisenberg, modern physics has indeed increased people's scepticism about language, but at the same time the implications of quantum theory have turned physics, and with it attempts to describe the world, against the overestimation of precise concepts. In this opposition - between an idealised language that seeks precise definition but that is nevertheless separated from the world, and a hazy language that evolves according to the pressures of 'reality' - we might see the same distinction between the poet of a poem like 'Lyrebirds' and that of 'Habitat' or 'The Dark Ones'. Understanding the late-modern world, replete with all of its quantum implications, requires for Heisenberg a new sense of the word 'understanding'. The new 'understanding' is a kind of incomplete understanding (whether this be based on a principle of uncertainty or of complementarity), a knowing of the world as an evolving, uncertain process rather than as a completely surveyable object. This is because 'understanding must be based finally upon the natural language', which 
changes over time. The important crux of his argument, therefore, is that, because of the basis of language in reality, 'we must be sceptical about any scepticism with regard to this natural language'. ${ }^{29}$

Mt Tamborine is the site at which Wright explores this new, limited form of understanding at first hand - eventually. For it would take many years for her to reach a point where she was comfortable with the smallness of her language and her thought entering into relatively free relation with a far larger eco-historical field. Prior to these late moments, what predominated was a desire to restrain the blinding light of the Romantic lyric, to check its visionary power by curtailing the very sight of its singer. What her work points to - which is part of the reason it has proved so influential for contemporary environmental and ecocritical discourse in this country - is what Mead, citing Paul Carter, calls 'the possibility of an "environmentally-grounded poetics". Central to Wright's preoccupations was a question that has become even more pressing in the globalised, late-capitalist context that has emerged since her death: 'Where and how are human beings to find a home?' In Australia, of course, this incorporates not only the issues of environmental sustainability and long-term land use, but the 'unsettling and unresolved question of land rights'. ${ }^{30}$ Perhaps one of the most important features of her legacy as a poet is to do with how this amalgamation of such crucial territorial and cultural concerns takes the Romantic lyric to its limits, where some of the very assumptions with which it operates - such as who can see what, and why - strain under the reverberation of too many unanswerable questions.

\section{Endnotes}

1 These books include: Woman to man (1949), The gateway (1953); The two fires (1955); Birds (1962); Five senses (the forest); The other half (1966); Shadow (1970); Alive (1973). Much of Fourth quarter, published in 1976, was also composed at Mt Tamborine.

2 See http://www.nprsr.qld.gov.au/parks/tamborine/culture.html.

3 Judith Wright, Collected poems: 1942-1985 (Sydney: Angus \& Robertson, 1994), p. 29.

4 Geoffrey H. Hartman, Beyond formalism: Literary essays 1958-1970 (New Haven, CT: Yale University Press, 1970), p. 228.

5 Wright, Collected poems, pp. 39-40

6 Wright, quoted in Gary Clark, 'The two threads of a life: Judith Wright, the environment and Aboriginality', Antipodes (December 2006), 156.

7 Wright, Collected poems, pp. 140-1.

8 Patricia Clarke and Meredith McKinney (eds), With love and fury: Selected letters of Judith Wright (Canberra: National Library of Australia, 2006), p. 276.

9 Stuart Cooke, Speaking the earth's languages: A theory for Australian-Chilean postcolonial poetics (Amsterdam: Rodopi, 2013), p. 41.

10 Wright, Collected poems, p. 176.

11 See Joan Retallack, The poethical wager (Berkeley, CA: University of California Press, 2003).

12 For example, see Judith Wright, Because I was invited (Melbourne: Oxford University Press, 1975), pp. 170-1.

13 Wright, Because I was invited, p. 31.

14 Judith Wright, Preoccupations in Australian poetry (Melbourne: Oxford University Press, 1965), p.129. 
15 Les Murray, Translations from the natural world (New York: Farrar, Straus and Giroux, 1994), p. 21.

16 See Les Murray and Judith Wright, 'Correspondence', Southerly, 63(1) (2003), 162-80.

17 Murray and Wright, 'Correspondence', 172.

18 Murray is most likely writing about the Superb Lyrebird, which, while relatively similar, has distinctive performative and physical characteristics to the Albert's.

19 Wright, Collected poems. p. 287

20 Martin Harrison, Who wants to create Australia? Essays on peetry and ideas in contemporary Australia (Sydney: Halstead Press, 2004), p. 75.

21 Harrison, Who wants to create Australia? pp. 76-7.

22 Philip Mead, Networked language: Culture \& history in Australian poetry (Melbourne: Australian Scholarly Publishing, 2008), pp. 318-19.

23 Mead, Networked language, p. 320.

24 Wright, Collected poems, p. 300.

25 Wright, Collected poems, p. 308.

26 Wright, Collected poems, p. 354.

27 Clark, 'The two threads of a life', 158-9.

28 Werner Heisenberg, Physics and philosophy: The revolution in modern science (Harmondsworth: Penguin, 2000 [1958]), p. 139.

29 Heisenberg, Physics and philosophy, p. 140.

30 Mead, Networked language, p. 328. 